\title{
柔軟で小型のバイオ蛣料電池の開発
}

\section{Flexible, miniature biofuel cell}

\author{
○学 大藤玩矢（東北大） 非 吉野修平（東北大） 非 加藤孝一朗（東北大） \\ 非 三宅丈雄（東北大） 正 梶弘和（東北大） 正 西澤松彦（東北大）
}

Takuya OFUJI, Shuhei YOSHINO, Koichiro KATO, Takeo MIYAKE, Hirokazu KAJ,

Matsuhiko NISHIZAWA, Tohoku University, Aramakiazaaoba6-6-1, Aoba-ku Sendai-shi, Miyagi

Key Words : biofuel cell, carbon fabric, carbon nanotube, gas-diffusion cathode, hydrogel

\section{1. 緒言}

近年, ウェアラブルデバイスを始めとする携帯型デバイス の注目に伴い，柔らかく小さい電源の開発が盛んである.と りわけ，身の周りに分散する低密度エネルギーを利用するユ ビキタス発電システムへの感心が高まっており, “安全・安 価で”環境負荷の小さい電源としてバイオ燃料電池にも期待 が寄せられている. 我々は, 高い性能と実用性を併せ持つバ イオ燃料電池を実現すべく,カーボンナノチューブを積極的 に利用した酵素修飾ナノ電極の開発，また体液/食物などか ら直接発電する刺入用電池の開発に取り組んだ. 本研究では, カーボンファブリック基板を用いた柔軟かつ高出力の酵素 電極を作製した. また，本電極をイオン電導性に優れるハイ ドロゲルと組み合わせることで, 柔軟で小型のバイオ然料電 池の開発も行った.

\section{2. 実験}

カーボンファブリック（炭素繊維織物）にカーボンナノチ ユーブ (CNT)を修飾した (Fig.1(a)). カソードでは酸素を還 元する酵素として Billirubin oxidase (BOD)を使用し, 空気中 の酸素を利用できる空気極を作製した (Fig.1(b))[1]. また， アノードはNADHの酸化に必要なメディエーター膜として, poly-Nile blue (pNB)を CNT 修飾後の電極表面に電解重合す ることにより作製した (Fig.1(c)). 作製した電極の性能はサ イクリックボルタンメトリ測定により評価した.さらに，グ ルコース，NAD+を含むハイドロゲルを本電極で挟み込むこ とでシート状の柔軟なバイオ燃料電池の作製も行った (Fig.1(d)).

\section{3. 結果}

アノードでは最大 $2.93 \mathrm{mAcm}^{-2}$ at $0.5 \mathrm{~V}$ (vs $\left.\mathrm{Ag} / \mathrm{AgCl}\right)$, カソ ードでは最大 $2.1 \mathrm{mAcm}^{-2}$ at $0 \mathrm{~V}$ (vs $\mathrm{Ag} / \mathrm{AgCl}$ )の電流密度が得 られた.また, 作製したバイ才燃料電池は開回路電圧 $0.78 \mathrm{~V}$, 最大出力密度 $164 \mu \mathrm{Wcm}^{-2}$ at $0.37 \mathrm{~V}$ を示した (Fig.2). 本発表 では, 電極の作製プロセスや電極の性能評価の詳細を報告す る予定である. (a)

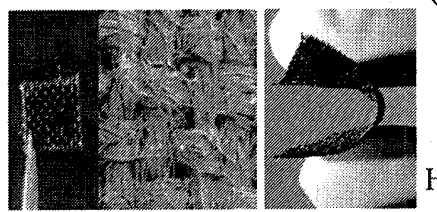

(b)

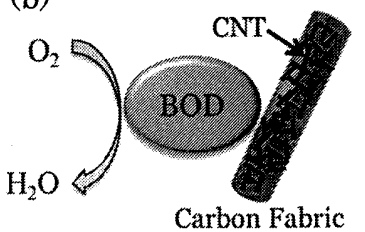

(c)

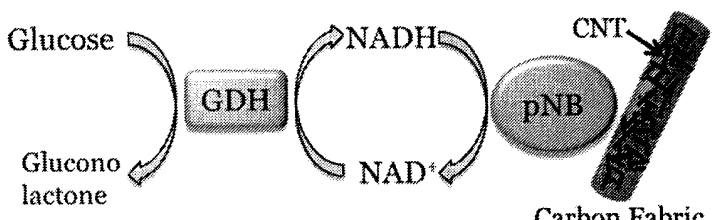

(d)

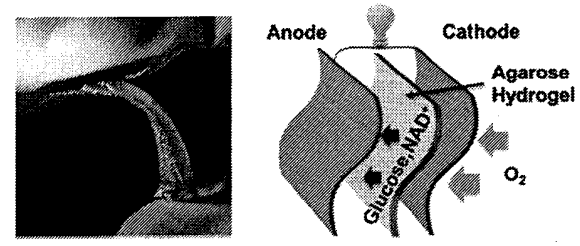

Fig.1 (a) CNT-modified carbon fabric

(b) Configuration of the cathode (c) Configuration of the anode (d) Biofuel cell

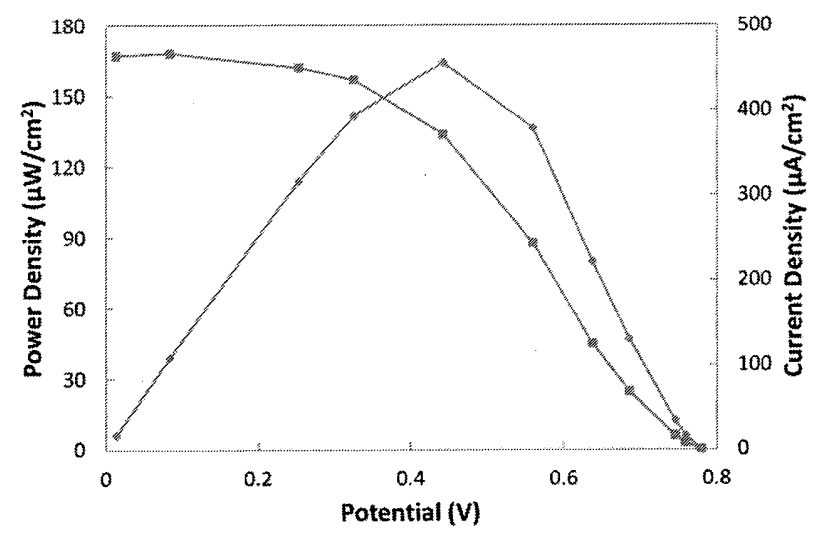

Fig.2 Performance of the sheet-shaped biofuel cell

\section{参考文献}

[1] T. Miyake, K. Haneda, N. Nagai, Y. Yatagawa, H. Onami, S. Yoshino, T. Abe and M. Nishizawa, Energy Environ. Sci., 2011, 4, 5008-5012 